\title{
Practicability Assessment of Smart Village Project: A Case of Sandakpur Rural Municipality, Ilam Nepal
}

\author{
Rajat Pokharel *, A. K. Mishra**, \& P. S. Aithal*** \\ * Master Research Scholar, Construction Management Program, Madan Bhandari Memorial \\ Academy Nepal, Urlabari -3, Morang, Email: rajatpokhrel@ gmail.com \\ **Post-Doctoral Research Scholar, Srinivas University, India and Associate Professor, \\ Madan Bhandari Memorial Academy Nepal, Urlabari3, Morang, Nepal \\ OrcidID: 0000-0003-2803-4918; Email: anjaymishra2000@ gmail.com \\ *** Professor, College of Management \& Commerce, Srinivas University, Mangalore, India \\ OrcidID: 0000-0002-4691-8736; E-mail: psaithal@gmail.com
}

Area/Section: Construction Management.

Type of the Paper: Ex-Post Facto Research.

Type of Review: Peer Reviewed as per $|\mathrm{C}| \mathrm{O}|\mathrm{P}| \mathrm{E} \mid$ guidance.

Indexed in: OpenAIRE.

DOI: https://doi.org/10.5281/zenodo.5799392

Google Scholar Citation: IJMTS

\section{How to Cite this Paper:}

Rajat Pokharel, Mishra, A. K., \& Aithal, P. S., (2021). Practicability Assessment of Smart

Village Project: A Case of Sandakpur Rural Municipality, Ilam Nepal. International Journal of Management, Technology, and Social Sciences (IJMTS), 6(2), 265-281. DOI: https://doi.org/10.5281/zenodo.5799392.

International Journal of Management, Technology, and Social Sciences (IJMTS)

A Refereed International Journal of Srinivas University, India.

CrossRef DOI: https://doi.org/10.47992/IJMTS.2581.6012.0170

(C) With Author.

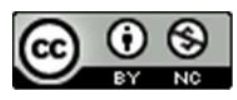

This work is licensed under a Creative Commons Attribution-Non-Commercial 4.0 International License subject to proper citation to the publication source of the work.

Disclaimer: The scholarly papers as reviewed and published by the Srinivas Publications (S.P.), India are the views and opinions of their respective authors and are not the views or opinions of the SP. The SP disclaims of any harm or loss caused due to the published content to any party. 


\title{
Practicability Assessment of Smart Village Project: A Case of Sandakpur Rural Municipality, Ilam Nepal
}

\author{
Rajat Pokharel *, A. K. Mishra**, \& P. S. Aithal*** \\ *Master Research Scholar, Construction Management Program, Madan Bhandari Memorial \\ Academy Nepal, Urlabari -3, Morang, Nepal, Email: rajatpokhrel@gmail.com \\ **Post-Doctoral Research Scholar, Srinivas University, India and Associate Professor, \\ Madan Bhandari Memorial Academy Nepal, Urlabari3, Morang, Nepal \\ OrcidID: 0000-0003-2803-4918; Email: anjaymishra2000@ gmail.com \\ *** Professor, College of Management \& Commerce, Srinivas University, Mangalore, India \\ OrcidID: 0000-0002-4691-8736; E-mail: psaithal@gmail.com
}

\begin{abstract}
Purpose: Villages are the backbone of the nation and a smart village means such a village that can provide various services needed in day-to-day life to the villagers effectively and efficiently. The overall objective of this research is to assess the practicability of the smart village in the hilly region of Nepal with the case of a Sandakpur Rural Municipality (SRM).

Design/Methodology/Approach: The study covered the area within Maipokhari and Sulubung village of Sandakpur Rural Municipality. Ontology and Epistemology philosophy of research was used as positivism. This research was intended to propose the model of smart village examined through a scheduled questionnaire in village sample of SRM, literature reviews related to smart village, and smart rural. This research proposed the smart village with the characteristics as Smart Utilization of Resources, Smart Living, Smart Governance, Smart Village Services, Smart Technology, Smart Tourism, and Gender Equity and Women Equity which can comply with some of the United Nations Sustainable Development Goals (SDGs). Five points Likert scale was used on ranking smart village feature and Chi-Square test is done to determine the significance of respondent's opinions for the variables from the collected data. After the analysis of data with the Five-Point Likert Scale, ratings on smart features were given as Fair (2.82), Fair (3.02), Fair (2.93), Fair (3.17), Fair (3.2), Good (2.42), and Poor (3.46) respectively.

Findings/Result: The chi-square test showed that the majority of respondents supported the perspective toward Smart Village features as fair. Smart villages can only be possible with long-term planning, strategy and investment. With the adoption offeatures of the smart village, the study area can be converted into a smart village but it may take time to incorporate these features completely The Smart village model is expected to be applied to villages in other regions by adjusting the characteristics of each region as every village has their own characteristics.
\end{abstract}

Originality/Value: It is action research to analyze the practicability of smart village development. It will be a method universal acceptable for assessing the feasibility of smart cities. The new concept will be fruitful for policymakers, Professionals, and nations for systematic development.

Paper Type: Ex-Post Facto Research.

Keywords: Smart Village, Information Technology, Sustainable Development, Equity, Services, SWOT analysis.

\section{INTRODUCTION :}

Nepal is a country with diverse geographic environments, including Terai (plain area), Hill, and Mountain, but in all these areas, the urbanization style is fast and uneven. The urbanization style is restricted normally in Kathmandu Valley and other some restrained cities of Terai. The result is that most of the massive cities are failing to cope with the demand of infrastructure offerings and job possibilities also are more and more dazzling beneath the penalties of the haphazard urbanization. In these large cities environmental degradation, congestion, city poverty, scattered settlements, 
unemployment and lagging provisions of infrastructure offerings have emerged as an increasingly more seen phenomenon (Mishra and Shah, 2018) [1].

The greater part of the settlement is in the hilly region of Nepal as it covers about $68 \%$ of the absolute territory. In any case, the greater part of the settlements is distant and in reverses because of the absence of least improvement amenities. The reality of the matter is that it is exceptionally hard to overhaul country towns to created urban communities as there are dispersed settlements and the majority of the amenities effectively available in urban can be costly because of geological conditions (Poudel, 2013) [2]. Smart villages are one of the ideas of developed villages in India. This idea was proposed by Viswanadham and Vedula in their book "Smart Village Design". Smart villages imitate the smart city model, integrating innovation and renewal in remote areas (Aziiza, 2020) [3]. A smart village is an allencompassing and comprehensive methodology for country advanced change towards accomplishing the SDGs in far-off and underserved communities where: (a) Rural inhabitants approach organize foundation using associated gadgets and services. (b) Citizens can get to significant and groundbreaking SDG-related advanced administrations, as they need them, on schedule, anyplace, and constantly. (c) Services are modified for the particular SDG needs of residents. (d) Integrated SDG-related administrations are persistently improving and adjusting to changes. (e) Partner associations included are consistently learning and adjusting their administrations (ITU, 2020) [4].

\section{PROBLEM STATEMENT :}

In Nepal, the municipalities are generally small and are given city status by consolidating a few Village Development Committees (VDCs). Indeed, the vast majority of the regions show rural characters, and the issues confronted are essentially contrasted with enormous urban communities of the populace at least 100,000 . The most of the village lacks basic infrastructures like clean drinking water, sanitation, irrigation facilities and electricity." Sandakpur Rural Municipality" located at the eastern part of Nepal Shares a border with India and also has very famous tourist spots but lacks basic infrastructures while it is considered deeply. Although agriculture is the basic occupation of this rural municipality and having potential for the medicinal herb industry people are backward as they even don't have their land and lack basic needs like clean drinking water, irrigation, and even ICT-based services.

\section{OBJECTIVES :}

The overall objective of the research is to analyse the Practicability of Smart Village Project with A case of Sandakpur Rural Municipality, Ilam Nepal. Following are specific objective.

(1) To develop an idea of the smart village with an institutional development plan and its integral features/attributes in the Nepalese context each for countrywide and local level via a literature assessment of worldwide practice cantered on developing countries.

(2) To analyse the technological advancement needed for the progression of the smart village with a case of Sandakpur Rural Municipality.

\section{LITERATURE REVIEW :}

Smart Village is a concept developed for remote rural areas. It provides solutions to all problems that arise and improves the quality of life of the people living there. The Smart Village will provide the necessary framework for everyone's development to lead a quality life of respect, equality, happiness and education, safety and livelihood. It will also create a perfect and feasible state through the use of smart solutions. The smart village was created through five overlapping approaches: Redevelopment, Retrofitting, Greenfields, E-Pan, and livelihood (Eco Needs Foundation, 2016) [5].

Table 1: Smart Village Concept

\begin{tabular}{|c|l|l|}
\hline S & Social, Skilled and Simple & $\begin{array}{l}\text { No discrimination on any tribe, caste and religion, } \\
\text { everyone is literate and Skilled with Simple living and } \\
\text { high thinking. }\end{array}$ \\
\hline M & $\begin{array}{l}\text { Moral, Methodical and } \\
\text { Modern }\end{array}$ & $\begin{array}{l}\text { Moral of Mahatma Gandhi, Swami Vivekananda and so } \\
\text { forth Methodical utilizing total literacy and most recent } \\
\text { methods Modern like urban areas. }\end{array}$ \\
\hline
\end{tabular}




\begin{tabular}{|c|l|l|}
\hline \hline A & $\begin{array}{l}\text { Aware, Adaptive and } \\
\text { Adjusting }\end{array}$ & $\begin{array}{l}\text { The most significant level of awareness on worldwide } \\
\text { social, economic and financial issues. Adaptive and } \\
\text { adjusting to quickly changing conditions. }\end{array}$ \\
\hline $\mathrm{R}$ & Responsive and Ready & $\begin{array}{l}\text { Responsive to aggregate intelligence, development and } \\
\text { bigger social issues Ready to produce own assets for } \\
\text { independence and self-reliance. }\end{array}$ \\
\hline $\mathrm{T}$ & $\begin{array}{l}\text { Techno-Savvy and } \\
\text { Transparent }\end{array}$ & $\begin{array}{l}\text { Techno-Savvy for IT and Mobile usage Transparent in } \\
\text { harmonic relations and delivery of services. }\end{array}$ \\
\hline
\end{tabular}

(S. Rutuja, 2016, A. Tripathi, 2019) [6]

Table 2: Literature Review

\begin{tabular}{|c|c|c|c|c|c|}
\hline S.N. & Title of paper & Country & $\begin{array}{l}\text { Characteristics } \\
\text { and focused area }\end{array}$ & Published on /By & $\begin{array}{l}\text { Year of } \\
\text { Publication }\end{array}$ \\
\hline 1 & $\begin{array}{l}\text { "Smart Village A } \\
\text { Sustainable Model } \\
\text { for Community } \\
\text { Development" }\end{array}$ & Bhutan & $\begin{array}{lr}\text { Smart } & \text { Village } \\
\text { model approach } \\
\text { focused r on } \\
\text { agriculture along } \\
\text { with technology } \\
\text { transfer }\end{array}$ & $\begin{array}{l}\text { Noppawan } \\
\text { Boontham, } \\
\text { Chomchuan } \\
\text { Boonrahong } \\
\text { Sathaporn Sangsupoh } \\
\text { and Surapol } \\
\text { Dumronggittigule }\end{array}$ & 2015 [7] \\
\hline 2 & $\begin{array}{l}\text { "Review on } \\
\text { Development of } \\
\text { Smart Villages" }\end{array}$ & India & $\begin{array}{l}\text { Implementations } \\
\text { of the Smart } \\
\text { Village concept } \\
\text { and the } \\
\text { importance of } \\
\text { digital } \\
\text { transformation for } \\
\text { rural areas }\end{array}$ & $\begin{array}{l}\text { Prof. Shahid Arshad, } \\
\text { Mohammad Mohsin, } \\
\text { Rizwan Khan, } \\
\text { Tanveer Khan, } \\
\text { Twinkle Ramteke }\end{array}$ & $2020[8]$ \\
\hline 3 & $\begin{array}{l}\text { "Clean and Smart } \\
\text { Village: Aspects } \\
\text { and Alternatives" }\end{array}$ & India & $\begin{array}{l}\text { Focus on water } \\
\text { supply, sanitation, } \\
\text { solid waste } \\
\text { management } \\
\text { development and } \\
\text { implementation }\end{array}$ & Milind Kulkarni & 2015 [9] \\
\hline 4 & $\begin{array}{l}\text { "Research on the } \\
\text { Beijing rural } \\
\text { villages" } \\
\text { classification \& } \\
\text { development } \\
\text { under } \\
\text { urbanization" }\end{array}$ & China & $\begin{array}{lr}\text { Village } & \text { System } \\
\text { Planning for } \\
\text { sustainable } \\
\text { development of } \\
\text { rural areas }\end{array}$ & Zhao Zhifeng & 2009 [10] \\
\hline 5 & $\begin{array}{l}\text { "Building } \\
\text { Villages: } \\
\text { blueprint as piloted } \\
\text { in Niger" }\end{array}$ & Nigeria & $\begin{array}{l}\text { Broadband } \\
\text { infrastructure } \\
\text { improves internet } \\
\text { access in rural } \\
\text { areas } \\
\text { promotes rural } \\
\text { digital } \\
\text { development and } \\
\text { transformation. }\end{array}$ & $\begin{array}{l}\text { International } \\
\text { Telecommunication } \\
\text { Union (ITU) }\end{array}$ & $2020[4]$ \\
\hline 6 & $\begin{array}{l}\text { "Smart Villages } \\
\text { Through } \\
\text { Information } \\
\text { Technology - } \\
\text { Need of Emerging } \\
\text { India" }\end{array}$ & India & $\begin{array}{l}\text { Application of } \\
\text { ICT and GIS for } \\
\text { Smart village } \\
\text { Development }\end{array}$ & $\begin{array}{l}\text { Pinak Ranade, Sunil } \\
\text { Londhe, Asima } \\
\text { Mishra }\end{array}$ & 2015 [11] \\
\hline
\end{tabular}




\begin{tabular}{|c|c|c|c|c|c|}
\hline 7 & $\begin{array}{l}\text { "Smart village a } \\
\text { case study of } \\
\text { Kolavada Village" }\end{array}$ & India & $\begin{array}{l}\text { Provide garbage } \\
\text { disposal, } \\
\text { sanitation } \\
\text { facilities and other } \\
\text { facilities to } \\
\text { promote the } \\
\text { development of } \\
\text { the village and } \\
\text { improve the } \\
\text { standard of living } \\
\text { and employment }\end{array}$ & $\begin{array}{l}\text { Bhagya Niranjanbhai } \\
\text { Patel, Prof. Rinni } \\
\text { Shah }\end{array}$ & 2017 [12] \\
\hline 8 & $\begin{array}{l}\text { "Study and } \\
\text { development of } \\
\text { village as a smart } \\
\text { village" }\end{array}$ & India & $\begin{array}{l}\text { Focus on resource } \\
\text { efficiency, local } \\
\text { self-government } \\
\text { and ensuring basic } \\
\text { needs }\end{array}$ & $\begin{array}{l}\text { Rutuja Somwanshi, } \\
\text { Utkarsha Shindepatil, } \\
\text { Deepali Tule, } \\
\text { Archana Mankar, } \\
\text { Namdev Ingle } \\
\text { Guided By- Dr. V. S. } \\
\text { Rajamanya, P. \& A. } \\
\text { Deshmukh }\end{array}$ & 2016 [6] \\
\hline 9 & $\begin{array}{l}\text { "Smart Village } \\
\text { Development } \\
\text { Principles And } \\
\text { Driving Forces: } \\
\text { The Case Of } \\
\text { Lithuania" }\end{array}$ & Lithuania & $\begin{array}{l}\text { Smart Village } \\
\text { development with } \\
\text { public } \\
\text { participation and } \\
\text { LEADER } \\
\text { approach }\end{array}$ & $\begin{array}{l}\text { Vilma Atkočiūnienė, } \\
\text { Gintare Vaznonienè }\end{array}$ & 2019 [13] \\
\hline 10 & $\begin{array}{l}\text { "Smart Villages: } \\
\text { New Thinking For } \\
\text { Off-Grid } \\
\text { Communities } \\
\text { Worldwide" }\end{array}$ & $\begin{array}{l}\text { University } \\
\text { of } \\
\text { Cambridge, } \\
\text { UK }\end{array}$ & $\begin{array}{l}\text { Energy for the } \\
\text { development and } \\
\text { employment } \\
\text { generation in the } \\
\text { village }\end{array}$ & Brian Heap & [14] \\
\hline 13 & $\begin{array}{l}\text { "Gender equity in } \\
\text { access to and } \\
\text { benefits from } \\
\text { modern energy and } \\
\text { improved energy } \\
\text { technologies } \\
\text { World } \\
\text { Development } \\
\text { Report } \\
\text { Background } \\
\text { Paper" }\end{array}$ & USA & $\begin{array}{l}\text { Improve women's } \\
\text { quality of life } \\
\text { through the use of } \\
\text { improved energy } \\
\text { technologies }\end{array}$ & $\begin{array}{l}\text { Joy Clancy, Tanja } \\
\text { Winther, Magi } \\
\text { Matinga and Sheila } \\
\text { Oparaocha, }\end{array}$ & 2012 [15] \\
\hline
\end{tabular}

\section{RESEARCH GAP :}

As of Nepal Budget Speech (2015/2016), Nepal Government proposed three cities to develop as a smart city named Palungtar from Gorkha District, Lumbini from Rupandehi District and Nijghad from Bara District and also process of developing 12 smart cities throughout the country moved forward. The Government of Nepal has not developed any regulatory documents which can illustrate the requirements for smart villages but the local government has proposed the smart village concept as the percentage of villages in Nepal is higher. So, it is beneficial to develop villages as a smart village rather than developing cities as smart. That is why the research is conducted with a view to analyze the international practice suitable in the Nepalese context and to assess the practicability of developing smart villages. 


\section{RESEARCH METHODOLOGY :}

\subsection{Study Area}

Sandakpur Rural municipality is located in the eastern part of Nepal and is an exceptionally renowned tourist destination for trekking. The study area is famous for its cool weather, homestay, and Mai Pokhari. After the restructuring of the local bodies, Sandakpur Rural Municipality is formed by agglomeration of 5 existing Village Development Committees, namely Maimajhuwa, Mabu, Sulubung, Jamuna, and Maipokhari VDCs. Out of these VDCs, Maipokhari VDC is partially merged whereas other VDCs are completely merged to form Sandakpur Rural Municipality. The study will be limited only to some specific settlement areas or villages of the Maipokhari and Sulubung areas. The specific features of the study area are:

$>$ Existing VDCs: Maipokhari, Sulubung VDCs

$>$ Restructured Structure: Sandakpur Rural Municipality Ward 1 and 3

$>$ Area: 48.86 sq. $\mathrm{km}$ (Ward -1 and 3 )

$>$ Location: $27.01 \mathrm{~N}, 87.93 \mathrm{E}$

$>$ No. of household:1374

$>$ Population Details

1. Male Population: 3027

2. Female Population: 3220

3. Total Population: 6247

4. Population density: 127.85

5. Average household size: 4

\subsection{Primary Data :}

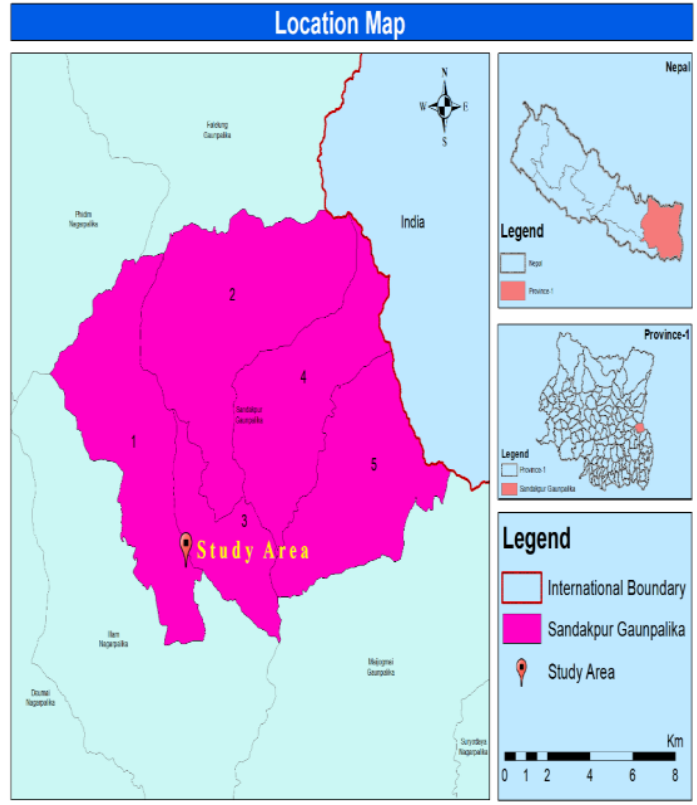

Fig. 1: Study Area

Primary data was collected through household interviews, scheduled questionnaire surveys and Key Informant Interview (KII).

The data collection followed the concept of inclusivity and primary data related to different sectors of the society was collected by enumerators. The major sectors of the study were:

$>$ Household Characteristics

$>$ Land use and agriculture

$>$ Social infrastructure (Sustainability, Equality, Security, Education, Health, and so forth)

$>$ Economy

$>$ Governance and public services

$>$ Issues of environmental concern

$>$ Access and Use of ICT infrastructure

\subsection{Secondary Data :}

Recent and reliable baseline data were extracted by secondary sources like office records or documents, municipality reports, ward profiles, distributed scholarly or expert reports, and information distributed by the Central Bureau of Statistics (CBS) [17] or other approved offices.

\subsection{Analysis of Data :}

Analysis was done utilizing Excel/SPSS programming, spatial investigation utilizing GIS programming, for example, ArcGIS and so on, and translation of aeronautical photos, maps accessible of various periods. Significant programming and framework were utilized to investigate the ICT situation. In this part, the following significant examination was done for assessing the specific objective of the research:

\section{A. The Idea of the Smart Village and Institutional Development}

a. Local-level enthusiasm and challenges for smart village

b. Local-level probability and need for ICT 
c. Land use

d. Infrastructure improvement.

e. Linkage of the proposed territory to local and national level

f. Reliability/Sufficiency

g. Sustainable Village and Communities

h. Public Information

i. Transparency and Accountability

\title{
B. Practicability Assessment
}

\author{
Likert Scale \\ To find the rank of the features of Smart Village, the Likert scale was used. The five-point scale \\ ranged from one to five was adopted. Interpretation on the Likert scale was done as: \\ Interpretation Range for Five-Point Likert Scale \\ $1=$ Excellent $\quad 1.00-1.80$ \\ $2=$ Good $\quad 1.90-2.60$ \\ $3=$ Fair $\quad 2.70-3.40$ \\ 4=Poor $\quad 3.50-4.20$ \\ 5=Very Poor $\quad 4.30-5.00$ \\ Average $=($ Sum of Opinion/Number of Respondents $)$
}
Testing of Hypothesis
To determine the significance of respondent's opinions for the variables from the collected data, a non-parametric test, the Chi-square test was conducted.
It is calculated as,
$\chi^{2}=\sum \frac{(\mathrm{O}-\mathrm{E})^{2}}{\mathrm{E}}$
Where,
$\chi^{2}=$ Chi-Squared
$\mathrm{O}=$ Observed Frequency
$\mathrm{E}=$ Expected Frequency
Null Hypothesis. $H_{0}: \mu_{1}=\mu_{2}$ i.e. There is no significant difference between the opinion of respondents.
Alternative Hypothesis. $H_{1}: \mu_{1} \neq \mu_{2}$ i.e. There is a significant difference between the opinions of respondents.

\section{RESULTS AND DISCUSSION :}

\subsection{Idea of Smart Village:}

After the literature review of different research of smart villages in the world, some of the characteristics are adopted that is suited the study area and the theme of the topic.

\section{A. Smart Utilization of Resources:}

For the upliftment of villages use of resources should be done in a well-organized manner. As agriculture is one of the main sources of income generation in the rural community. It is the most adopted employment by rural dwellers. Through the process of technology transfer and use of modern technologies like drip and sprinkler irrigation productivity can be increased. Natural resources and human resources available there, with their proper utilization, contribute to the development of villages. Pollution of the environment can be reduced by the use of natural resources and a friendly environment can be achieved by plantation (Rutuja, 2016) [18]. "The assessment of technology transfer achievement into the community economy is necessary to consider the important indicators which consist of progress, efficiency, effectiveness, impacts, relevance, sustainability, and equity" (Boontham, 2015) [7].

Smart Utilization of Resources is the key to a sustainable country, so many countries are using biological calculators, ecological calculators to make a balance between consumption and production of resources. During the questionnaire survey, it was found that the people here are mostly dependent on natural resources, agriculture, medicinal herbs and livestock. They are generating income with the 
natural resource available i.e., tourists are attracted here because of the pleasant environment and natural beauty.

\section{B. Smart Living:}

Smart life is defined as the use of technology \& the interest in things to pursuit a more efficient, controllable \& productive lifestyle. Use of recent technologies in the field of ICT along with better fundamental needs like fresh and good food, safe and clean drinking water, better sanitation, environmental protection, digester management and security. Not only are these enough, facilities like well-managed roads, sports areas and parks, banking are also the necessity of smart living.

There is a need of Smart Villages for both rural and urban areas for better livelihood and technology. Livelihood is affected in urban areas due to the migration of rural people as technological support already exists at the urban side (Shahid, 2020) [8].

Smart living changes the dimension of life with the improvement in lifestyle, environment and awareness. During KII it was found that the lifestyle of the people must be changed and the village lacks most of the facilities like health, better educational institutes, sanitation, well-managed roads, etc. which are the basic requirements for smart living. Infrastructure and awareness are needed which can change the lifestyle of the village.

\section{Smart Governance:}

Smart Village relies on good governance such as open (i.e., transparent), accountable, collaborative (i.e., involving all stakeholders) and participatory (i.e., citizens' participation) principles and on Electronic Government (e-Government) which sustains the smart village. To maintain transparency and public participation there is a need of smart governance.

Participation of local people in the local development plan to translate the foregoing activities into possible actions by using local and appropriate tools. Regular and punctual attendance of government staff with time-bound services and delivery inline in each department are some characteristics of smart governance (Rutuja, 2016) [18].

With the formation of local government local people are getting services a bit fast and efficiently but during the survey, it was found that upgrading of infrastructures and manpower was the prime need of the village.

\section{Smart Village Services:}

Essential services like health and education along with economic services like job availability, entrepreneurship and site for economic activities like shops, markets, etc. are required in the smart village.

Village development can only be accelerated if we promote urban-rural integrated development; combine the land development with industrial development; cluster these villages; and build a network of infrastructure and facilities for each village cluster (Zhifeng, 2009) [10].

When people become smart, definitely the surroundings they live on become smart. During the survey, the village services which are needed for the day-to-day life were found to lack well-equipped infrastructures and services provided by them were below the average.

\section{E. Smart Technology:}

To develop the village as smart village internet availability is the most. For that development and construction of IT infrastructure is most which can further develop appropriate rural technologies.

The deployment of IT in rural areas, helps rural communities to develop social innovation and to maintain residential development. Social innovation and the organizational culture of a rural area, which are a self-regulatory mechanism of the local community, helps in monitoring the adherence to the smart village principle (Atkočiūnienè, 2019) [13].

The knowledge of new and productive tools which make life easy is technologies. During KII it was found that most people use a mobile phone, schools were not able to provide computer education, there was no equipment in the health post and the recent technologies used in the field of agriculture were not seen. So there was a need for modern agriculture equipment, tools recent technologies in the health sector, awareness and education

\section{F. Smart Tourism:}

To increase the productivity and lifestyle of rural dwellers tourism is the most important factor. It flourishes the identity of the village at a national and global level. The village can further enhance and share their culture and tradition and attract tourists as a new tourist destination.

"To make village tourism sustainable and to promote it through the concept of sustainability, the especial target should focus on to host a high quality-low number of tourists rather than a low qualityhigh number" (Thapa, 2010) [19]. 
Tourism can change the prospectus of the village and the country. During the survey, it was found that the village has the possibility of tourism but it lacked well-equipped hotels, homestays, roads, and other infrastructure. The implementation of smart tourism, adventure tourism, accessible tourism, and agritourism can change the lifestyle of the village.

\section{G. Gender Equity and Women Empowerment:}

Gender equity recognizes that women and men have different needs and interests, and that to achieve equality in life outcomes, a redistribution of power and resources is required (Reeves and Baden, 2000) [16].

Self-respect and confidence can only be achieved by women when they have economic empowerment; it is a way for others to see them as equal members of society. Women play a significant role in the development of the family and the whole country (Rutuja, 2016) [6].

During The survey, it was found that children in the village are getting their primary education, women have participated in local government, and some are doing their own occupation. Chaupadi Pratha, which is a tradition that banishes females during menstruation is absent here which shows their condition is not worst. But the problem of child marriage was seen which hampered mostly girls' education which results in a female literacy rate of $69.11 \%$ which is lower than the male literacy rate of $82.21 \%$ according to census report 2011. Although women were self-empowered they were still dominated in society.

\subsection{Institutional Development Plan:}

For any city or village to develop, they require institutions that are central to sustainable and beneficial economic growth. Institutions create policies, mobilize and manage the resources, and deliver the services which stimulate and sustain development. If the institutions which guide them are dysfunctional, growth and prosperity are unlikely to be maintained (McGill R. 1996) [20].

\section{Goal and Strategy of Institutional Development:}

\section{(1) Smart and Dynamic Governance:}

To promote sustainable development and enhance residents' capacity to address the environmental and development issues local government plays an important role. For the government to be smart and dynamic it should possess characteristics like efficiency, transparency, social integration, effectiveness, continuous improvement with improved and advance use of modern technology and communication. The most important aspects of smart governance are E-governance and the involvement of the public in the decision-making process.

\section{(2) Ensure Public Participation:}

When public concerns, needs, and values are incorporated into governmental and corporate decisionmaking, it is called public participation. The overall goal of public participation is better decisions that are supported by the public which is followed by two-way communication and interaction.

In Nepal, the concept of public participation was visualized in the Local Self Governance Act 1999. Formation of local bodies and providing them with the power to establish the civil society based on a democratic process with transparency and accountability along with public participation was its main motto. The legislative provision of public participation was disrupted locally due to uncertainty of local election until 2016. Until 2016 the central government was only the body that continuously reformed the structure and processes of public participation so that people can participate in the local policymaking process. After the formation of local bodies in Nepal, with the increase in policy-making power, public participation became successful to some extent.

\section{(3) Ensure Local Legislation with Economic and Sustainable Development:}

Local legislation means the power of the local body to make its own rules and regulation and formulate and maintain within its boundary. After the formation of local government in Nepal, they make their own rule and regulation without crossing the limit of the constitution of Nepal which ensures the availability of relevant ordinances in support of social, economic development, and environmental management.

With the formation of local government, it prioritized areas with pronounced needs or inadequate services and areas that benefit the greater majority also identify areas of great economic potentials.

\section{Activities for Institutional Development:}

1. Development of e-municipal service system and related training and awareness programs.

2. Promotion and adaptation of e-procurement system. 
3. Implementation of bylaws and building code.

4. Promotion of Gender Equality and Social Inclusion (GESI) in municipal organizational structure.

5. Promotion \& Development of the public-private partnership.

6. Construction of digital information boards in each ward office

Smart Village can only be successful if there is good coordination between three levels of government i.e. local, state and central.

\subsection{Technological Development Plan:}

Smart Villages are the need of the present scenario of the world as development is needed for both rural and urban areas for better livelihood and Information technology will offer effective solutions. Geoinformatics helps to transform villages into smart villages because it can represent an important step towards the use and implementation of ICT in "smart villages" in terms of decision support systems. In order to support innovative solutions for management, governance and citizen participation practices that meet the goals of smart villages, recently developed technologies such as GIS, GPS, remote sensing, web services, and location-based services and technologies may be the best choice. Other than these some basic technologies most for smart villages are:

a. ICT Infrastructures like the construction of network towers, an extension of fibre optics cable for communication and internet, public Wi-Fi, website and app of the village with regular update and control center of ICT services.

b. Well maintained road with a drainage system, street light, Bus Park, market and park for refreshment.

c. School and college with ICT facility.

d. Health center with well-equipped instruments, ambulance, and manpower.

e. Construction of Reservoir tank with treatment plant, manpower, and public stand post.

f. The solar home system, biogas as cooking fuel, improved cooking stove, etc.

g. Installation of devices for weather monitoring and training for the disaster management team.

h. Use of handy agriculture tools like hand tractors for ploughing, sprinkler irrigation, and drip irrigation where water quantity is less.

i. Solid Waste collection vehicles and solid waste treatment setup.

j. Construction of public toilets with the sewerage system.

k. Retrofitting of old houses and construction of the new house as earthquake resistance.

1. Construction of area police station and installation of a security camera at the prime junction.

The study area is located in Sandakpur Rural Municipality [21-23] named Maipokhari and Sulubung village in Ilam district of Province 1, Nepal. It is approximately $13 \mathrm{~km}$ away from Ilam Bazar. The selection of the village is that it lies in the tourism loop on the way to the famous Sandakphur and also has a famous religious and tourist spot named Maipokhari. The area has a moderate climate prevailing the highest average temperature of $26^{\circ} \mathrm{C}$ in June and the lowest is $16^{\circ} \mathrm{C}$ in January. There is a lot of rainfall in summer $\&$ in the winter it is quite dry again. There is about $1157 \mathrm{~mm}$ rain in a year.

\subsection{Practicability Status of Sandakpur Municipality}

Data collected through scheduled questionnaires were analyzed and interpreted using the Likert Scale to know the practicability status as shown in table 3 .

Table 3: Likert Scale Table

\begin{tabular}{|l|l|l|l|l|l|l|l|}
\hline $\begin{array}{l}\text { Number of } \\
\text { Respondents/Variables }\end{array}$ & Excellent & Good & Fair & Poor & $\begin{array}{l}\text { Very } \\
\text { Poor }\end{array}$ & Average & Interpretation \\
\hline $\begin{array}{l}\text { Smart Utilization of } \\
\text { Resources }\end{array}$ & 0 & 14 & 26 & 4 & 1 & 2.82 & Fair \\
\hline Smart Living & 1 & 10 & 23 & 9 & 2 & 3.02 & Fair \\
\hline Smart Governance & 1 & 11 & 24 & 8 & 1 & 2.93 & Fair \\
\hline Smart Village Services & 0 & 6 & 26 & 12 & 1 & 3.17 & Fair \\
\hline Smart Technology & 0 & 6 & 27 & 9 & 3 & 3.2 & Fair \\
\hline
\end{tabular}




\begin{tabular}{|l|l|l|l|l|l|l|l|}
\hline \hline Smart Tourism & 10 & 10 & 21 & 4 & 0 & 2.42 & Good \\
\hline $\begin{array}{l}\text { Gender Equity and } \\
\text { Women Empowerment }\end{array}$ & 0 & 2 & 25 & 13 & 5 & 3.46 & Poor \\
\hline
\end{tabular}

From table 3, it is very clear that at present in the village, resource utilization and their living are just fair and they are getting services from the government not in well managed but in a decent way. The village economy is dependent on agriculture and tourism and is giving more priority to infrastructures for tourism but the village is still behind the recent technologies that urban people utilize. Every feature needed for a smart village is on the way to improve but the women were found still backward from the surveyed data. To determine the significance of respondent's opinions for the variables from the collected data, a non-parametric test, the Chi-Square test was conducted with a 5\% level of significance. Table 4 shows the result of the Chi-square test.

Table 4: Result of Chi-Square Test

\begin{tabular}{|l|l|l|}
\hline Statement & Chi-Square p-value & Result \\
\hline $\begin{array}{l}\text { Null Hypothesis. } \mathrm{H}_{0}: \mu_{1}=\mu_{2} \text { i.e. There is no } \\
\text { significant difference between the opinion of } \\
\text { respondents. }\end{array}$ & 1.39577E-07 & $\begin{array}{l}1.39577 \mathrm{E}-07<0.05, \mathrm{H}_{1} \text { is } \\
\text { accepted }\end{array}$ \\
$\begin{array}{l}\text { Alternative Hypothesis. } \mathrm{H}_{1}: \mu_{1} \neq \mu_{2} \text { i.e. There } \\
\text { opinions of respondents. }\end{array}$ & & \\
\hline
\end{tabular}

Since the calculated value of the Chi-square p-value is less than 0.05 , alternate hypothesis $\mathrm{H}_{1}$ is accepted. Therefore, there is a significant difference between the opinions of respondents. Hence, every respondent has a different opinion, the priority is given to the dominating value i.e., from table 4, the majority of respondents supported the perspective toward smart village features as fair.

\subsection{Discussion Using SWOT Analysis on Practicability of Smart Village:}

SWOT Analysis is a strategic technique for the analysis of Strengths, Weaknesses, Opportunities, and Threats [24] in any project or development plan. SWOT analysis of smart village features in the study area is done as:

Table 5: SWOT Analysis

\begin{tabular}{|c|c|c|c|c|c|}
\hline S.N & Features & Strength & Weakness & Opportunity & Threat \\
\hline 1 & $\begin{array}{l}\text { Smart } \\
\text { Utilization of } \\
\text { Resources }\end{array}$ & $\begin{array}{l}\text { - More than } 90 \% \\
\text { of the land is } \\
\text { used for } \\
\text { agriculture } \\
\text { purposes. } \\
\text { - Self-Sustained } \\
\text { family. } \\
\text { - Kiwi farming, } \\
\text { Dairy products, } \\
\text { medicinal herbs, } \\
\text { etc. are the } \\
\text { source of } \\
\text { income. }\end{array}$ & $\begin{array}{ll}\text { - } & \text { Lack of } \\
\text { well- } \\
\text { managed } \\
\text { irrigation } \\
\text { facility. } \\
\text { - } \text { Lack of } \\
\text { proper } \\
\text { market. } \\
\text { - Lack of } \\
\text { employment } \\
\text { opportunity. }\end{array}$ & $\begin{array}{l}\text { - Construction } \\
\text { of dairy } \\
\text { processing } \\
\text { plants } \\
\text { - Development } \\
\text { of Agro- } \\
\text { Based } \\
\text { market } \\
\text { - Employment } \\
\text { opportunity } \\
\text { in factory } \\
\text { and market. }\end{array}$ & $\begin{array}{ll}\text { - } & \begin{array}{l}\text { Poor road } \\
\text { connectivit }\end{array} \\
\text { y } \\
\text { - } & \text { Land } \\
\text { plotting } \\
\text { - } \\
\text { Climate } \\
\text { change } \\
\text { - Less } \\
\text { interest of } \\
\text { younger } \\
\text { people in } \\
\text { agriculture }\end{array}$ \\
\hline 2 & Smart Living & $\begin{array}{l}\text { - Ease in road } \\
\text { access as } \\
\text { connected to } \\
\text { National }\end{array}$ & $\begin{array}{l}\text { - The absence } \\
\text { of } \\
\text { blacktopped } \\
\text { road and } \\
\text { road are not }\end{array}$ & $\begin{array}{l}\text { - National } \\
\text { Highway } \\
\text { linkage to } \\
\text { the } \\
\text { municipality }\end{array}$ & $\begin{array}{ll}- & \text { Lack of } \\
\text { proper road } \\
\text { services so } \\
\text { the chance }\end{array}$ \\
\hline
\end{tabular}




\begin{tabular}{|c|c|c|c|c|c|}
\hline & & $\begin{array}{l}\text { Highway in } \\
\text { Barbote. } \\
\text { - } 90 \% \text { of } \\
\text { households have } \\
\text { a clean and } \\
\text { quality water } \\
\text { supply } \\
\text { - Management of } \\
\text { solid waste at } \\
\text { the household } \\
\text { level } \\
\text { - 100\% electricity } \\
\text { and } \\
\text { telecommunicati } \\
\text { on } \\
\text { - Availability of } \\
\text { health posts and } \\
\text { more than } 33 \\
\text { schools } \\
\text { throughout the } \\
\text { municipality. }\end{array}$ & $\begin{array}{l}\text { accessed to } \\
\text { the } \\
\text { household. } \\
\text { - Supply of } \\
\text { water is only } \\
\text { from RVT, } \\
\text { no provision } \\
\text { of rainwater } \\
\text { harvesting } \\
\text { Lack of } \\
\text { proper } \\
\text { dumping site } \\
\text { and no } \\
\text { segregation } \\
\text { of waste. } \\
\text { Fluctuation } \\
\text { in the supply } \\
\text { of electricity } \\
\text { due to poor } \\
\text { electric } \\
\text { poles and } \\
\text { poor } \\
\text { connectivity. } \\
\text { Lack of } \\
\text { college for } \\
\text { higher } \\
\text { education } \\
\text { and absence } \\
\text { of facilitated } \\
\text { hospital. }\end{array}$ & $\begin{array}{l}\text { - Enough } \\
\text { water supply } \\
\text { sources can } \\
\text { be converted } \\
\text { to } 100 \% \text {. } \\
\text { - Biogas can } \\
\text { be the best } \\
\text { option for } \\
\text { energy and } \\
\text { have enough } \\
\text { space for a } \\
\text { dumping } \\
\text { site. } \\
\text { - Solar Energy } \\
\text { can be the } \\
\text { best option } \\
\text { for regular } \\
\text { electricity. } \\
\text { - Educational } \\
\text { institutions } \\
\text { can be } \\
\text { upgraded to } \\
\text { higher } \\
\text { secondary } \\
\text { and under } \\
\text { construction } \\
\text { of } 15 \text { bedded } \\
\text { hospital. }\end{array}$ & $\begin{array}{l}\text { of } \\
\text { migration. } \\
\text { There is no } \\
\text { proper } \\
\text { treatment } \\
\text { plant for } \\
\text { water } \\
\text { supply so } \\
\text { the chance } \\
\text { of water- } \\
\text { borne } \\
\text { diseases. } \\
\text { Pollution } \\
\text { of solid and } \\
\text { incarnated } \\
\text { waste } \\
\text { within the } \\
\text { entire } \\
\text { municipalit } \\
\text { y. } \\
\text { Poor } \\
\text { infrastructu } \\
\text { re for the } \\
\text { supply of } \\
\text { electricity } \\
\text { and poor } \\
\text { internet } \\
\text { connection. } \\
\text { Challenges } \\
\text { in the up- } \\
\text { gradation } \\
\text { of } \\
\text { educational } \\
\text { institutions } \\
\text { due to land } \\
\text { availability } \\
\text { and poor } \\
\text { health } \\
\text { education. }\end{array}$ \\
\hline 3 & $\begin{array}{l}\text { Smart } \\
\text { Governance }\end{array}$ & $\begin{array}{l}\text { - Formation of } \\
\text { local } \\
\text { government. } \\
\text { - Having own } \\
\text { infrastructure } \\
\text { with integration } \\
\text { of IT. }\end{array}$ & 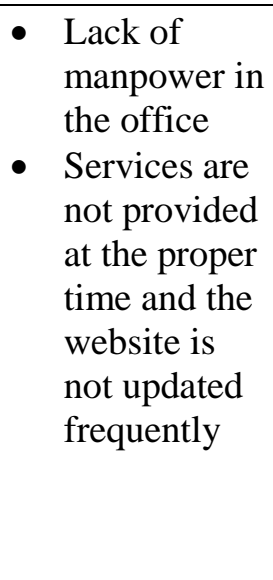 & $\begin{array}{l}\text { - The } \\
\text { decision- } \\
\text { making } \\
\text { power of } \\
\text { local } \\
\text { representativ } \\
\text { es } \\
\text { - Plan and } \\
\text { program } \\
\text { don't rely } \\
\text { mostly on } \\
\text { the central } \\
\text { government }\end{array}$ & $\begin{array}{ll}- & \text { Planning is } \\
\text { not well } \\
\text { optimized. } \\
\text { - Not fully } \\
\text { Independen } \\
\text { t. }\end{array}$ \\
\hline
\end{tabular}




\begin{tabular}{|c|c|c|c|c|c|}
\hline 4 & $\begin{array}{l}\text { Smart } \\
\text { Village } \\
\text { Services }\end{array}$ & $\begin{array}{l}\text { - Rural } \\
\text { municipality } \\
\text { services and } \\
\text { other available } \\
\text { services of } \\
\text { office are a bit } \\
\text { fast due to } \\
\text { availability of } \\
\text { internet. } \\
\text { - Schools are } \\
\text { providing } \\
\text { computer-based } \\
\text { subjects. } \\
\text { - Under } \\
\text { constructed } \\
\text { hospital can start } \\
\text { their services } \\
\text { online and } \\
\text { offline. } \\
\text { - Job } \\
\text { opportunities } \\
\text { can be created in } \\
\text { the field of } \\
\text { agriculture with } \\
\text { digitization. }\end{array}$ & 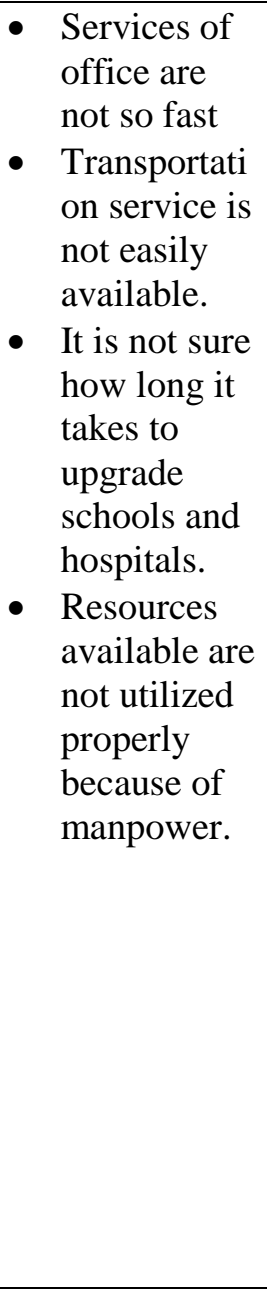 & $\begin{array}{l}\text { - ICT center } \\
\text { and free Wi- } \\
\text { Fi hotspot } \\
\text { can be } \\
\text { provided } \\
\text { - E- } \\
\text { government } \\
\text { is possible if } \\
\text { a fast } \\
\text { connection to } \\
\text { the internet } \\
\text { is provided. } \\
\text { - Mobile } \\
\text { banking } \\
\text { digital } \\
\text { payment } \\
\text { methods can } \\
\text { be } \\
\text { integrated. } \\
\text { - The } \\
\text { establishmen } \\
\text { t of a } \\
\text { medicinal } \\
\text { herb } \\
\text { processing } \\
\text { plant can } \\
\text { increase } \\
\text { income } \\
\text { generation. }\end{array}$ & $\begin{array}{l}\text { - Availability } \\
\text { of fund } \\
\text { - Due to } \\
\text { topography, it } \\
\text { costs more, } \\
\text { and not easy } \\
\text { to provide a } \\
\text { fast } \\
\text { connection to } \\
\text { the internet. } \\
\text { - Digital apps } \\
\text { can't be } \\
\text { handy to all } \\
\text { persons. }\end{array}$ \\
\hline 5 & $\begin{array}{l}\text { Smart } \\
\text { Technology }\end{array}$ & $\begin{array}{l}\text { Availability of } \\
\text { mobile internet, } \\
\text { smartphones. }\end{array}$ & $\begin{array}{l}\text { Poor } \\
\text { coverage of } \\
\text { mobile } \\
\text { signals and } \\
\text { the internet } \\
\text { most of the } \\
\text { elderly } \\
\text { people don't } \\
\text { know to use } \\
\text { smartphones }\end{array}$ & $\begin{array}{l}\text { - Can } \\
\text { strengthen } \\
\text { mobile } \\
\text { internet, } \\
\text { providing } \\
\text { proper } \\
\text { training and } \\
\text { connection } \\
\text { of fibre } \\
\text { internet. } \\
\end{array}$ & $\begin{array}{l}\text { Topography } \\
\text { is the only } \\
\text { main reason } \\
\text { for the } \\
\text { hindrance of } \\
\text { infrastructure } \\
\text { development. }\end{array}$ \\
\hline 6 & $\begin{array}{l}\text { Smart } \\
\text { Tourism }\end{array}$ & $\begin{array}{l}\text { - Location of } \\
\text { famous religious } \\
\text { and tourist site } \\
\text { i.e., Maipokhari } \\
\text { Ramsar Site } \\
\text { - Kiwi Zone of } \\
\text { Minister } \\
\text { Agriculture } \\
\text { Modernization } \\
\text { and cultivation } \\
\text { of medical } \\
\text { herbs. }\end{array}$ & $\begin{array}{l}\text { - Hilly } \\
\text { topography } \\
\text { and } \\
\text { infrastructur } \\
\text { e for tourism } \\
\text { are not well } \\
\text { managed. } \\
\text { Limited } \\
\text { transportatio } \\
\text { n facility. }\end{array}$ & $\begin{array}{l}\text { - Possibility of } \\
\text { the best } \\
\text { tourist spot } \\
\text { with the } \\
\text { availability } \\
\text { of the best } \\
\text { infrastructure } \\
\text { s. } \\
\text { - The } \\
\text { medicinal } \\
\text { herb industry } \\
\text { can be } \\
\text { established. }\end{array}$ & $\begin{array}{l}\text { - Animal } \\
\text { Trafficking } \\
\text { and } \\
\text { exploitation } \\
\text { of medical } \\
\text { herbs }\end{array}$ \\
\hline 7 & $\begin{array}{l}\text { Gender } \\
\text { Equity and } \\
\text { Women }\end{array}$ & $\begin{array}{l}\text { - There is no } \\
\text { discrimination in } \\
\text { providing }\end{array}$ & $\begin{array}{l}\text { In villages } \\
\text { there is still } \\
\text { child } \\
\text { marriage can }\end{array}$ & $\begin{array}{l}\text { - Enforcement } \\
\text { and } \\
\text { education } \\
\text { can prove }\end{array}$ & $\begin{array}{l}\text { Poverty and } \\
\text { education are } \\
\text { the reasons } \\
\text { for women's }\end{array}$ \\
\hline
\end{tabular}




\begin{tabular}{|c|c|c|c|c|}
\hline $\begin{array}{l}\text { Empowerme } \\
\text { nt }\end{array}$ & $\begin{array}{l}\text { education to all } \\
\text { the gender. } \\
\text { - Participation of } \\
\text { women in local } \\
\text { government. } \\
\text { - Women are } \\
\text { mostly engaged } \\
\text { equally in } \\
\text { agriculture, } \\
\text { homestay } \\
\text { business, and the } \\
\text { cultivation of } \\
\text { medicinal herbs. }\end{array}$ & $\begin{array}{l}\text { be found } \\
\text { which led } \\
\text { girls to drop } \\
\text { out of school } \\
\text { at an early } \\
\text { age. } \\
\text { Although } \\
\text { women are } \\
\text { engaged in } \\
\text { local } \\
\text { government, } \\
\text { they have } \\
\text { not been } \\
\text { treated } \\
\text { equally } \\
\text { because of a } \\
\text { male- } \\
\text { dominated } \\
\text { society. }\end{array}$ & $\begin{array}{l}\text { girls and } \\
\text { boys are } \\
\text { equal in all } \\
\text { aspects. } \\
\text { - The } \\
\text { establishmen } \\
\text { t of the } \\
\text { agriculture } \\
\text { industry can } \\
\text { provide an } \\
\text { opportunity } \\
\text { for women to } \\
\text { rise. }\end{array}$ & $\begin{array}{l}\text { backwardness } \\
\text { - } \text { Poor } \\
\text { institutional } \\
\text { development } \\
\text { plan for the } \\
\text { right of } \\
\text { women. }\end{array}$ \\
\hline
\end{tabular}

\section{CONCLUSION AND RECOMMENDATION :}

The development of the village as a Smart Village is not a one-day target. It needs stepwise development and a plan. Going through the literature around the globe, it can be concluded that a smart village is only one step towards development that can provide basic facilities and infrastructure that can solve problems of the village without interfering with village rule and regulation. It just boosts up the village lifestyle so that village people can link directly or indirectly with the world.

\subsection{Conclusion:}

The research study shows that rural territories are now in the phase of development and the development process is not as fast and effective as expected. To implement the smart village features like Smart Utilization of Resources, Smart Living, Smart Governance, Smart Village Services, Smart Technology, Smart Tourism, and Gender Equity and Women Equity initially. There is a need of proper institutional documents comprising regulatory guidelines which guide every stage of development of the smart village and inspect the indicators or features. Findings indicate that the rural areas are now on the verge of development as they are recently linked with the national road network, infrastructures like the hospital, school, water supply, irrigation are in the phase of improvement which is making rural life easy Therefore, the present situation is such that complete development of smart village cannot be achievable as it was found the majority of respondents supported the perspective of smart village features as fair and individual ratings on smart village feature were given as Fair (2.82), Fair (3.02), Fair (2.93), Fair (3.17), Fair (3.2), Good (2.42) and Poor (3.46) respectively from five-point Likert scale and the services and facilities available in the village doesn't completely comply with smart village features. With the proper policy, facilities and services which can assure the compliance of indicators and features, successful implementation of smart villages can be done.

\subsection{Recommendation:}

1. Institutions should adopt minimum indicators or features as Smart Utilization of Resources, Smart Living, Smart Governance, Smart Village Services, Smart Technology, Smart Tourism, and Gender Equity and Women Equity.

2. Proper training, guidance and user education must be provided to the consumers, stakeholders and implementing agency to overcome the incompetence of indicators or features.

3. Proper and sufficient security arrangements shall be made for the safety of visitors, existing biodiversity, and components of the area with cultural values.

4. Necessary by-laws act, a legal framework for carrying out various work like, construction, land acquisition and institutional documents comprising regulatory guidelines which guide every 
stage of development of the smart village project is needed to be developed by the province and local government.

5. The establishment of an IT centre, a school with higher-level education, a hospital with adequate facilities, a proper water treatment plant with one tap one house policy and sanitation system, cheap electricity and fuel for cooking to every house, an awareness program to control child marriage and training for women empowerment and a well-furnished road with cheap transportation modalities is recommended initially for smart village project.

\subsection{Recommendation for Further Study:}

1. Smart Village is a concept adopted by developed nations so there must be much more planning, study, and homework before implementation of any projects.

2. Every village has different characteristics, so the development model of one village could be only a reference for the further analysis of a particular village.

\section{ACKNOWLEDGEMENT :}

The work is done under the regulatory provisions of Madan Bhandari Memorial Academy Nepal, Urlabari 3, Morang and Pokhara University, Nepal. We are thankful to them.

\section{REFERENCES :}

[1] Mishra, A. K. and Shah, S., (2018). Estimating Housing Unit for Low Income Group of People in Kathmandu, Nepal. NOLEGEIN-Journal of Operations Research \& Management, 1(1). 16-27. Available at: https://doi.org/10.37591/njorm.v1i2.185

https://scholar.google.com/citations?view op=view citation\&hl=en\&user=70NJhYAAAAAJ\&c start=20\&pagesize $=80 \&$ citation_for_view=70NJhYAAAAAJ:0EnyYjriUFMC

[2] Poudel, K. P. (2013). National development plan and urbanization in Nepal. In 12th International Asian Urbanization Conference on Urban Dynamics, Environment and Health: Challenges for the Twenty First Century. Department of Geography, Banaras Hindu University, India (pp. 1-16). Available at: https://www.researchgate.net/profile/Krishna-PoudelONAL DEVELOPMENT PLAN AND URBANIZATION IN NEPAL/links/54e5b4830cf276cec17475 89/NATIONAL-DEVELOPMENT-PLAN-AND-URBANIZATION-IN-NEPAL.pdf

[3] Aziiza, A. A., \& Susanto, T. D. (2020). The Smart Village Model for Rural Area (Case Study: Banyuwangi Regency). In IOP Conference Series: Materials Science and Engineering (Vol. 722, No. 1, p. 012011). IOP Publishing. Retrieved from: https://scholar.google.com/scholar?hl=en\&as $\mathrm{sdt}=0 \% 2 \mathrm{C} 5 \& \mathrm{q}=\mathrm{A}+\mathrm{smart}+\mathrm{village}+$ model+followed +a+model+from+smart+city+as+an+effect+of+integrated+technology+changes+to+be+impleme nted+in+the++remote++areas\&btnG=

[4] ITU, (2020). Building Smart Villages: A Blueprint. 2020. Geneva, Switzerland: International Telecommunication Union (ITU) Available at: https://www.itu.int/dms_pub/itu-d/opb/str/D-STRSMART_VILLAGE.NIGER-2020-PDF-E.pdf [Assessed on Oct 15, 2020].

[5] Foundation, Eco Needs, (2016). Smart Village: Smart Village Dhanora Is the New Model of Village Development. Smart Village (blog), August 29, 2016. Accessed from: https://smartvillagedhanora.blogspot.com/2016/08/smart-village-dhanora-is-new-model-of.html

[6] Somwanshi, R., Shindepatil, U., Tule, D., Mankar, A., Ingle, N., Rajamanya, G. B. D. V., \& Deshmukh, A. (2016). Study and development of village as a smart village. International Journal of Scientific \& Engineering Research,7(6), 395-408.Retrieved from: https://scholar.google.com/scholar?hl=en\&as_sdt=0\%2C5\&q=Study+and+Development+of+Vill age+as+a+Smart+Village \&btnG=

[7] Boontham N, et al. (2015); Smart Village - A Sustainable Model for Community Development: Available http://www.bhutanstudies.org.bt/2015GNHConference/Paperfor2015GNHConference/9.SMART \%20Village Noppawan.pdf 
[8] Shahid, A. et.al, (2020). Review on Development of Smart Villages, International Journal of Scientific Research in Science and Technology (IJSRST), 5(7), 392-396. Available at: https://ijsrst.com/\%20IJSRST205786

[9] Kulkarni, (2015). Clean and Smart Village: Aspects and Alternatives. International Journal of Research in Engineering, Science and Technologies - Civil Engineering, 1(3), 19-23, Retrieved from:

https://www.researchgate.net/publication/289685973_Clean_Village_and_Project_Based_Learni ng.

[10] Zhifeng, Z. (2009). Research on the Beijing Rural Village Classification \& Development under Urbanization. The 4th International Conference of the International Forum on Urbanism (IFoU), Beijing, China, 2009, pp. 1387-1394.

[11] Ranade, P., Londhe, S., \& Mishra, A. (2015). Smart villages through information technology-need of emerging India. IPASJ International Journal of Information Technology (IIJIT), 3(7), 1-6. Available

at: https://scholar.google.com/scholar?q=SMART+VILLAGES+THROUGH+INFORMATION+TE CHNOLOGY+\%E2\%80\%93+NEED+OF+EMERGING+INDIA\&hl=en\&as_sdt=0\%2C5\&as_yl o=2015\&as_yhi $=$

[12] Patel, B. N., \& Shah, R. (2017). Smart village a case study of Kolavada village. International 20/Research Journal of Engineering and Technology, 2(12). Retrieved from: https://scholar.google.com/scholar?hl=en\&as_sdt=0\%2C5\&as_ylo=2015\&q=Smart+village $+\mathrm{a}+\mathrm{c}$ ase+study+of+Kolavada+village \&btnG=

[13] Atkočiūnienè, (2019). Smart Village Development Principles and Driving Forces: The Case of Lithuania. European Countryside, 11(4), 497-516. Retrieved From: https://doi.org/10.2478/euco2019-0028.

[14] Smart Villages, 2020. New Thinking for Off-Grid Communities Worldwide.Smartvillage, [Online]. Available on: http://e4sv.org/ about-us/what-are-smart-villages/ [Assessed on Dec 25, 2020].

[15] Clancy, J. S., Winther, T., Matinga, M. N., \& Oparaocha, S., 2012. Gender equity in access to and benefits from modern energy and improved energy technologies: world development report background paper. ETC/ENERGIA in association Nord/Sør-konsulentene. Retrieved From: https://openknowledge.worldbank.org/bitstream/handle/10986/9207/WDR20120029.pdf? sequence $=1 \&$ is Allowed $=\mathrm{y}$

[16] Reeves, H. and Baden, S., (2000). Gender and Development: Concepts and Definitions. Prepared for the Department for International Development (DFID). Brighton, UK: BRIDGE, Institute of Development Studies.

Google Scholar

[17] CBS, (2012). National population and housing census 2011. Kathmandu, Nepal: Central Bureau of Statistics (CBS).Retrieved from: https://cbs.gov.np/

[18] Somwanshi, R., Shindepatil, U., Tule, D., Mankar, A., Ingle, N., Rajamanya, G. B. D. V., \& Deshmukh, A. ,2016. Study and development of village as a smart village. International Journal of Scientific \& Engineering Research, 7(6), 395-408.Retrieved from: https://scholar.google.com/scholar?q=Study+and+Development+of+Village+as+a+Smart+Villag e.\&hl=en\&as_sdt=0\%2C5\&as_ylo=2016\&as_yhi $=$

[19] Thapa, (2010). Village Tourism Development \& Management in Nepal: A Case Study of Sirubari Village. Ecoclub [online], Retrieved From: <https://ecoclub.com/education/articles/488-sirubarivillage-tourism-nepal> [Accessed 17 Jun 2021].

[20] McGill, R., (1996). Defining Institutional Development (ID). In: Institutional Development. Palgrave Macmillan, London. Retrieved from: https://doi.org/10.1007/978-1-349-25071-4_1

[21] Creighton, James, L. (2005). The public participation handbook: making better decisions through citizen involvement. ISBN 0-7879-7307-6 (alk. paper). 1. Political participation. The United 
States.

Handbooks,

manuals,

etc.

Available

at:

https://smartnet.niua.org/sites/default/files/resources/Public\%20Participation\%20Handbook.pdf

[22] MOFAGA, (2017). Local Self Governance Act 1999. Ministry of Federal Affairs and General Administration (MOFAGA). Law Books Management Board, Nepal. Available at:https://www.lawcommission.gov.np/en/wp-content/uploads/2018/10/local-self-governanceact-2055-1999.pdf

[23] SRM, (2020). Sandakpur Rural Municipality Profile 2020.Sandakpur Rural Municipality (SRM). Ilam, Nepal. Retrieved From: https://www.sandakpurmun.gov.np/

[24] Aithal, P. S., \& Kumar, P. M. (2015). Applying SWOC analysis to an institution of higher education. International Journal of Management, IT and Engineering, 5(7), 231-247.

Google Scholar

$* * * * * * *$ 